\title{
Texture-modified food and fluids in dementia and residential aged care facilities
}

\author{
This article was published in the following Dove Press journal: \\ Clinical Interventions in Aging \\ 2 August 2017 \\ Number of times this article has been viewed
}

\author{
Virginia Painter ${ }^{\prime}$ \\ David G Le Couteur ${ }^{1-3}$ \\ Louise MWaite ${ }^{1-3}$ \\ 'Aged and Chronic Care Department, \\ Concord Repatriation General \\ Hospital, Concord, NSW, Australia; \\ ${ }^{2}$ Ageing and Alzheimer's Institute, \\ Concord Repatriation General \\ Hospital, Concord, NSW, Australia; \\ ${ }^{3}$ Centre for Education and Research \\ on Ageing, University of Sydney, \\ Concord, NSW, Australia
}

\begin{abstract}
Introduction: Dysphagia is common in people living with dementia and associated with increased risk of aspiration pneumonia, dehydration, malnutrition, and death. Treatment options are limited and the use of texture-modified food and fluids (TMF) is a widespread clinical practice. This review aimed to evaluate the evidence for TMF in dementia.

Methods: A literature search using terms "dysphagia," "texture-modified food and fluids," "dementia," and "aged care" was performed by using three electronic databases from 1990 to March 2017. Studies were assessed for suitability, then reviewed with data extracted, and grouped by categories of outcome measures.

Results: A total of 3,722 publications were identified, and 22 studies met the inclusion criteria. Studies were heterogeneous in design and methodology. There were no publications examining dementia exclusively; however, many subjects with dementia were included in studies of residential aged care facilities. TMF reduced the risk of aspiration seen on videofluoroscopy but not clinical aspiration and pneumonia. TMF was associated with lower daily energy and fluid intake and variable adherence.

Conclusion: There is a lack of evidence for people living with dementia and in residential care facilities that TMF improves clinical outcomes such as aspiration pneumonia, nutrition, hydration, morbidity, and mortality. Adverse effects including poorer energy and fluid intake were identified.
\end{abstract}

Keywords: modified diet, dysphagia, aspiration, aged care, nursing homes, dehydration, nutrition

\section{Plain language summary}

Texture-modified food and fluids (TMF) are used by many people in residential aged care facilities and are likely to be widely used in people living with dementia. TMF reduces aspiration detected by imaging but has not been shown to have impact on clinical outcomes including aspiration pneumonia. TMF may have negative effects on nutrition and hydration.

\section{Introduction}

Dysphagia is a common problem in older people and occurs in one half or more of people in residential aged care facilities and those living with dementia. ${ }^{1,2}$ The mechanisms for dysphagia are multifactorial, and factors that influence swallowing are advancing age, apraxia, cognitive fluctuation, impulsivity, reduced physical mobility, poor dentition, and dependence for feeding and medications. ${ }^{2,3}$ Dysphagia is a major risk factor for poor outcomes including aspiration pneumonia, malnutrition, dehydration, reduced functional status, increased hospital length of stay, and hospital re-admissions. ${ }^{1,2,4,5}$

Management options for dysphagia are limited. Texture-modified food and fluids (TMF, Table S1) were first studied in people with stroke and non-progressive
Correspondence: Louise M Waite Aged and Chronic Care Department, Concord Repatriation General Hospital, Hospital Rd, Concord, NSW 2139, Australia

Tel +6129767 72/2

Email louise.waite@sswahs.nsw.gov.au (c)
hereby accept the Terms. Non-commercial uses of the work are permitted without any further permission from Dove Medical Press Limited, provided the work is properly attributed. For permission for commercial use of this work, please see paragraphs 4.2 and 5 of our Terms (https://www.dovepress.com/terms.php). 
dysphagia but are now used commonly in dementia and residential aged care facilities. However, there is limited evidence that the use of TMF results in significant positive health outcomes in stroke. ${ }^{6}$ Moreover, poor acceptability and adherence to TMF may contribute to reduced quality of life, malnutrition, and dehydration. ${ }^{4}$

A recent international expert meeting on oropharyngeal dysphagia in older people concluded that there is not enough good quality evidence to recommend the use of TMF for the reduction of aspiration pneumonia risk and that there is some evidence that it cannot increase dietary or fluid intake for elderly people with chronic dysphagia. ${ }^{7,8}$ There have been three earlier systematic reviews on TMF specifically in people with dementia. ${ }^{9-11}$ These identified only two relevant studies ${ }^{12,13}$ and provided mixed recommendations. Alagiakrishnan et al concluded that TMF may be helpful despite variable efficacy for the prevention of aspiration. ${ }^{9}$ Both Affoo et $\mathrm{al}^{10}$ and Hanson et $\mathrm{al}^{11}$ concluded that TMF might reduce aspiration but does not have any impact on long-term morbidity and mortality. Another review ${ }^{14}$ focused on people in residential care and concluded that best practice could not be established, although it was suggested that thickened fluids may be effective if prescribed by a speech pathologist and prepared properly. There is a proposed Cochrane Review of TMF in people with dementia. ${ }^{4}$

Given the prevalence of dementia and its strong association with dysphagia, understanding the role of TMF for management is crucial for guiding decision-making by clinicians, patients, and their carers. This review aimed to identify and evaluate the evidence for the use of TMF in people with dementia and in residential care.

\section{Methods}

\section{Search strategy}

Relevant studies from 1990 to July 2016 were identified through a literature search of multiple electronic databases (PubMed, MEDLINE, and Cochrane Library) in May 2014, June 2015, July 2016, and March 2017 by VP. Search terms for "dysphagia" and "texture-modified food and fluids" were combined with the terms for "dementia" and "aged care" (Table S2). The reference lists of identified publications were hand-searched for additional studies.

\section{Selection criteria}

Clinical studies were included if they were written in English, TMF was used as the intervention, and the studies examined the effect of TMF on at least one clinically relevant outcome. There were no studies that exclusively focused on dementia.
Study populations entirely consisting of patients with dysphagia secondary to stroke and non-progressive neurological conditions were excluded. Article titles and abstracts were reviewed for suitability with exclusion of duplicates, literature reviews, case studies, and commentaries. If suitability was unclear, the article was read in its entirety.

\section{Data extraction}

The following data were extracted from the included articles and reviewed: study design, description of study population, size of study, duration of study, nature of intervention, outcomes including benefits and adverse effects, and investigators' conclusion. Data were summarized in tables grouped by categories of outcome measures and was too heterogeneous to be subjected to pooled numerical or statistical analyses.

\section{Results}

The database search identified 3,692 results and the reference lists identified a further 30 results, representing a total of 3,722 articles. Title and abstract review excluded 3,662 articles, leaving 60 articles for full-text review. Twentytwo published studies were identified that met the inclusion criteria (Figure 1).

\section{Prevalence of TMF}

There were two studies ${ }^{15,16}$ where prevalence for TMF was the main objective and three studies ${ }^{17-19}$ where this could be extrapolated (Table S3). The prevalence of TMF varied between $8 \%$ and $67 \%$ in people living in residential care facilities, and subjects receiving TMF were more likely to have dementia (43.0\% vs 33.0\%,P<0.02). ${ }^{15}$ Indications for TMF included choking, feeding dependency, esophageal disease, poor dentition, refusal to eat, and cognitive deficits. ${ }^{15,16}$

\section{Aspiration}

There were six studies that included subjects with dementia that have examined primary outcomes relating to aspiration in TMF (Table 1). ${ }^{3,12,13,20-22}$ The proportion of subjects with dementia ranged from $2 \%$ to $84 \%$. Subjects primarily came from residential care, but also included hospital inpatients and community-dwelling subjects.

Two studies investigated the relationship between modified fluids and aspiration as demonstrated on videofluoroscopic swallowing studies (VFSS) while a third study utilized a self-composed screening tool as its measure of aspiration. Logemann et $\mathrm{al}^{12}$ found that the risk of aspiration on VFSS was reduced on thin fluids with chin down 


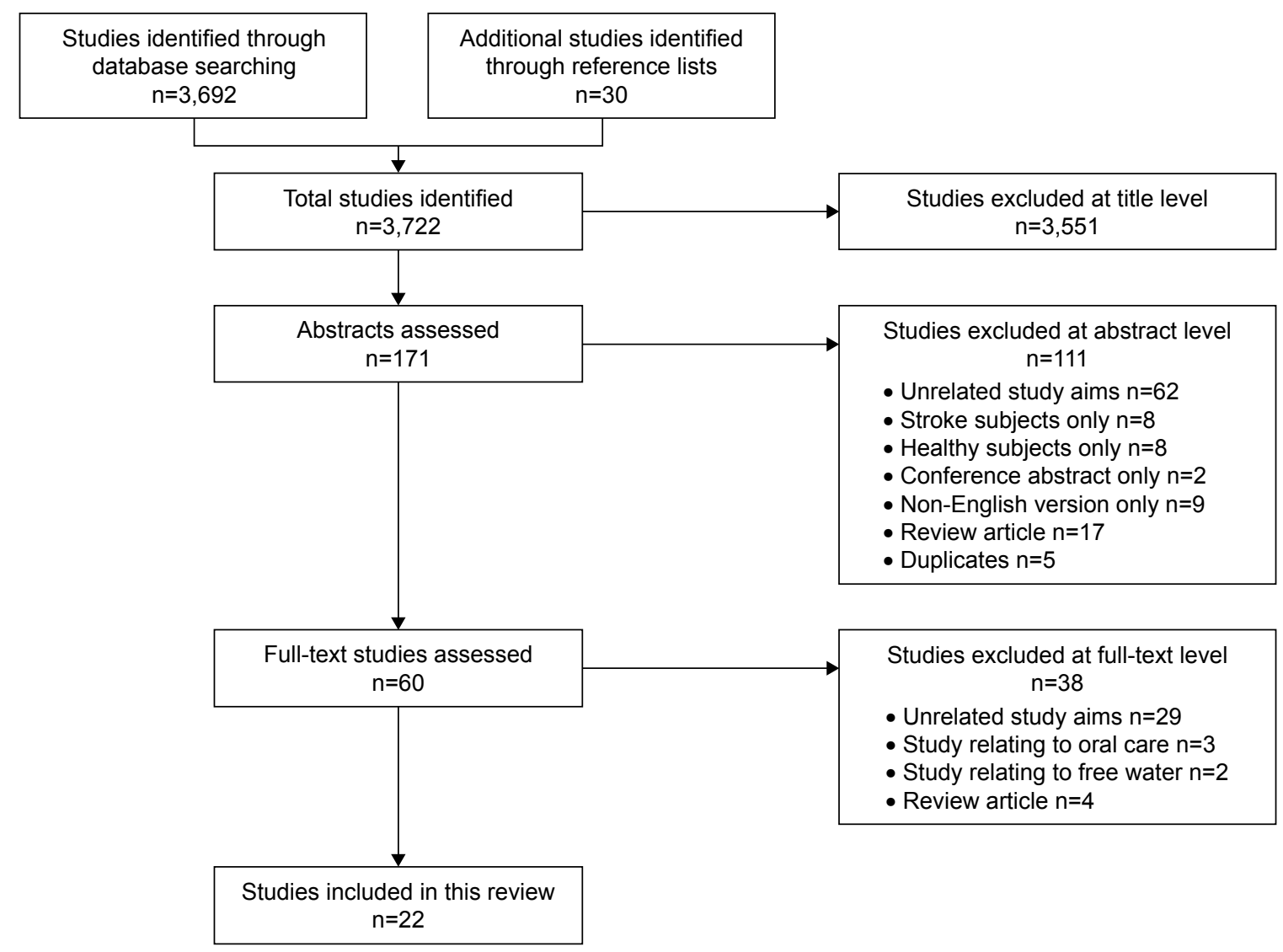

Figure I Flow diagram of the selected studies.

posture, mildly thick fluids, and extremely thick fluids and that the risk was significantly reduced as modified fluid became thicker $(68 \%$ vs $64 \%$ vs $53 \%, P<0.001)$. It was noted that more than half of the subjects with dementia aspirated on all three interventions. ${ }^{12}$ Leder et al found that moderately and extremely thick fluids were equally effective for reducing aspiration. ${ }^{3}$ Rosler et al used a screening tool based on the assessment of an immediate speech pathologist to define aspiration and found that risk was reduced as patients transitioned from water to sliced apple to pureed apple. ${ }^{20}$

Three studies investigated clinical outcomes of pneumonia, hospital admission, or death. ${ }^{13,21,22}$ Robbins et al found no difference in the incidence of pneumonia and death over 3 months for thin fluids with chin down posture and thickened fluids (hazard ratio 0.163 vs $0.205,95 \%$ confidence interval 0.43-1.36). ${ }^{13}$ Taniguchi et al found that TMF was associated with the increased incidence of hospital admission and death over 1 year. ${ }^{21}$ Low et al reported the only study showing improved clinical outcomes with TMF; however, the control group were subjects who were non-adherent with TMF. There were significantly more hospital admissions and deaths due to aspiration in non-adherent patients. There was no difference in the number of lower respiratory tract infections. ${ }^{22}$

\section{Nutrition}

Ten studies reported nutritional outcomes associated with TMF (Table 2). ${ }^{13,17,18,23-29}$ Most were performed in the residential care setting with an unspecified proportion of patients with dementia. Two studies were performed in acute hospital inpatients in neurology and aged care wards. ${ }^{23,24}$

Five studies compared daily energy and protein intake on normal diet versus TMF. ${ }^{18,23,25-27}$ Statistical significance was achieved in three studies where patients on TMF tended to have lower energy intake $\mathrm{e}^{18,23,25}$ and lower protein intake ${ }^{23}$ than when they were on a normal diet.

Robbins et al reported that $1.5 \%$ of subjects on thin fluids with chin down posture and $2.3 \%$ of subjects on thickened fluids had weight loss over 3 months. ${ }^{13}$ Massoulard et al correlated the type of diet with baseline nutritional status and found no significant association although the subgroups were small. ${ }^{27}$

Two studies investigated whether nutritional outcomes could be improved using novel approaches to TMF. ${ }^{17,28}$ 


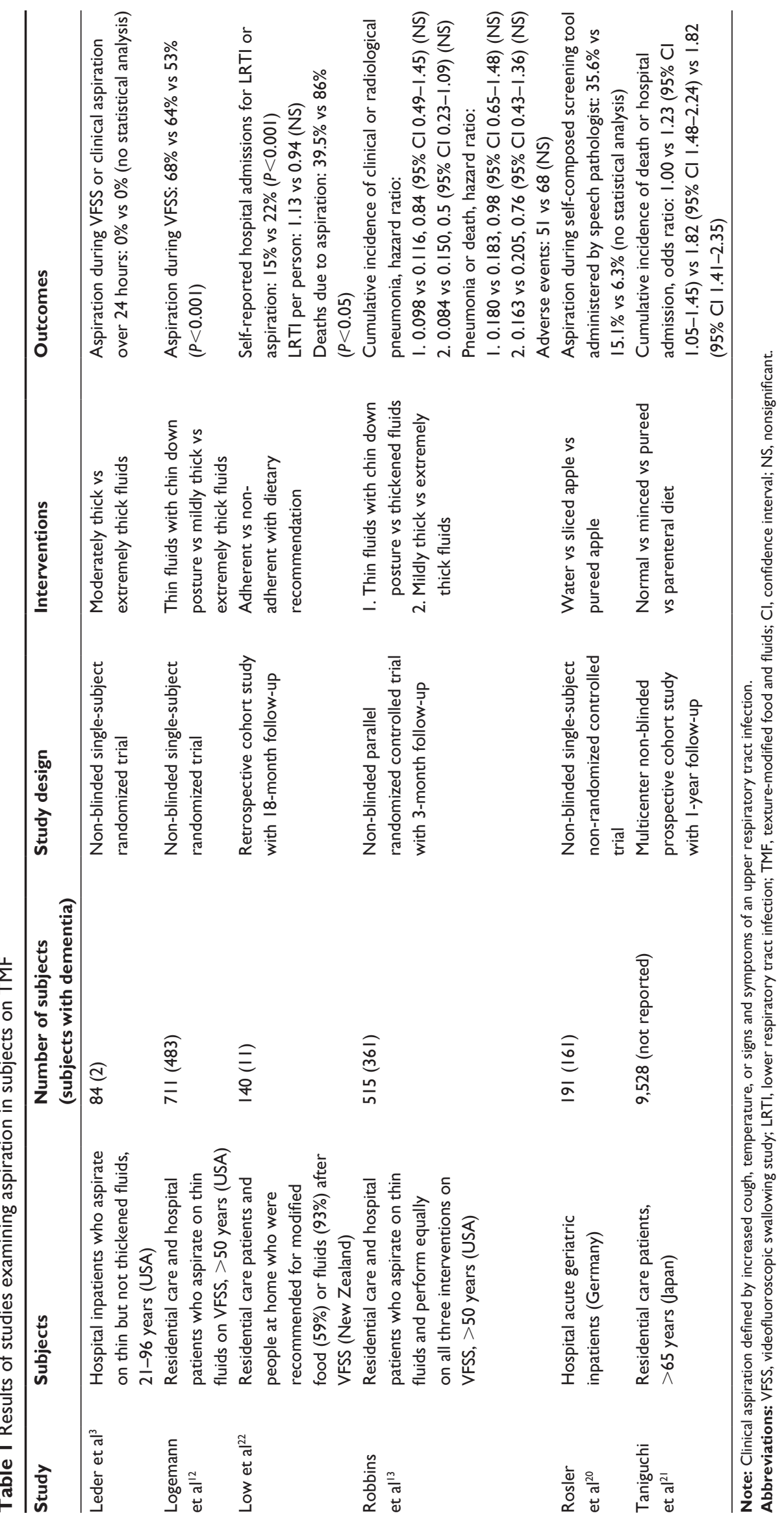




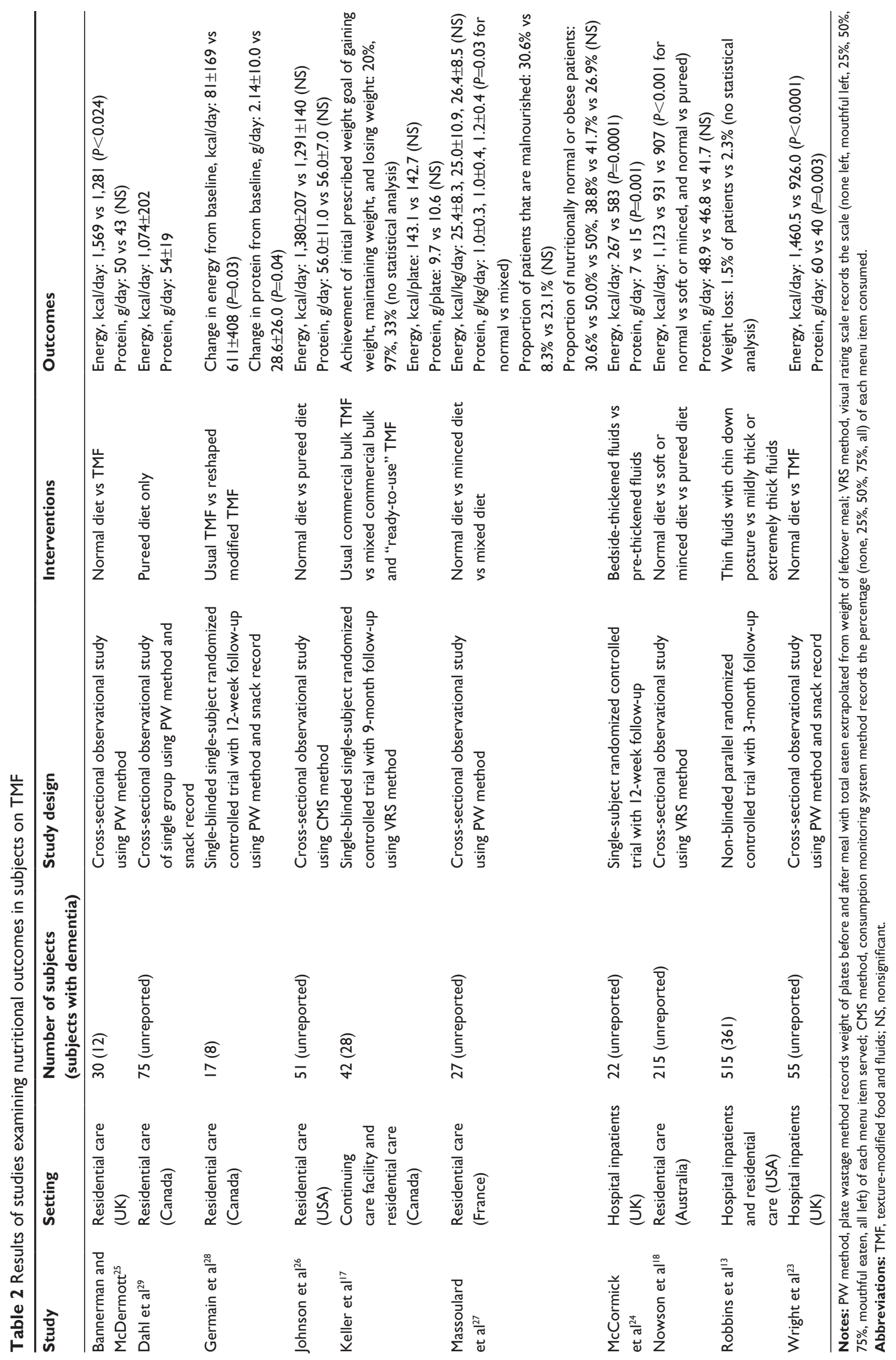


Germain et al found improved energy and protein intake over 12 weeks in a small randomized controlled trial where TMF was reshaped to look more similar to their original appearance. ${ }^{28}$ Keller et al mixed a similar product with usual commercial bulk TMF and found that most subjects were able to maintain their weight though there were no differences in energy and protein intake. ${ }^{17}$

\section{Hydration}

Three studies examined total daily fluid intake as a primary outcome in people on $\mathrm{TMF}^{24,25,30}$ and one study reported data on dehydration as an adverse outcome ${ }^{13}$ (Table 3 ). These studies were in hospital inpatients and patients in residential care.

Bannerman and $\mathrm{McDermott}{ }^{25}$ noted that patients on TMF had lower total daily fluid intake than patients on a normal $\operatorname{diet}(1,196$ vs $632 \mathrm{~mL}, P<0.002)$. Only $6.7 \%$ of patients on a modified diet met their daily fluid requirements compared with $33.3 \%$ of patients on a normal diet. ${ }^{25}$ Vivanti et al studied 25 hospital inpatients on thickened fluids and found that none achieved their daily fluid requirements without enteral or parenteral fluid support. ${ }^{30}$ McCormick et al did not find any significant difference in total daily fluid intake based on the method of preparation of thickened fluids. ${ }^{24}$

Robbins et al reported that $2.3 \%$ of subjects on thin fluids with chin down posture and $5.9 \%$ of subjects on mildly and extremely thick fluids had dehydration as diagnosed by a primary care physician. Statistical analysis was only performed for a combined outcome of dehydration, urinary tract infection, and fever which was not significant (5\% vs $9 \%$, $P=0.055){ }^{13}$

\section{Adherence}

Three studies have investigated adherence to TMF as the primary outcome ${ }^{31-33}$ and two studies as the secondary outcome $^{13,22}$ (Table S4). Figures for non-adherence range from $10 \%$ to $52 \%$.

Shim et al found better adherence with hospital inpatients but not with age, type of food or fluid modification, symptoms of aspiration, or severity of dysphagia. ${ }^{31}$ Low et al reported that non-adherent patients were more likely to be younger, from home, and on thickened fluids rather than modified diet. ${ }^{22}$

Rosenvinge and Starke found that non-adherence in inpatients was more likely when TMF was inappropriately prepared or the wrong texture was provided. ${ }^{32}$ A multidisciplinary approach led to an improvement in adherence to thickened fluids after 2 months from $48 \%$ to $64 \%$.

\section{Discussion}

This review identified 22 studies that investigated the use of TMF in people living with dementia, primarily in residential aged care facilities. There were no studies of people with dementia exclusively, and most of the studies were in residential aged care facilities where many of the subjects had dementia. Five major outcomes were identified in these studies: prevalence of TMF, aspiration, nutrition, hydration, and adherence.

There are no data for the prevalence of use of TMF exclusively in people with dementia, but as many as twothirds of people in residential care are using TMF. The wide range in the prevalence of TMF in the studies identified is secondary to the different types of residential care settings

Table 3 Results of studies examining total daily fluid intake in subjects on TMF

\begin{tabular}{|c|c|c|c|c|c|}
\hline Study & Setting & $\begin{array}{l}\text { Number of subjects } \\
\text { (subjects with dementia) }\end{array}$ & Study design & Interventions & Outcomes \\
\hline $\begin{array}{l}\text { Bannerman and } \\
\text { McDermott }\end{array}$ & $\begin{array}{l}\text { Residential care } \\
\text { (UK) }\end{array}$ & $30(12)$ & $\begin{array}{l}\text { Cross-sectional } \\
\text { observational study using } \\
\text { standard cup weights }\end{array}$ & Normal diet vs TMF & $\begin{array}{l}\text { Total daily fluid intake: } \\
\mathrm{I}, \mathrm{I} 96 \mathrm{vs} 632 \mathrm{~mL} \\
(P<0.002)\end{array}$ \\
\hline McCormick et al ${ }^{24}$ & $\begin{array}{l}\text { Hospital inpatients } \\
\text { (UK) }\end{array}$ & 22 (unreported) & $\begin{array}{l}\text { Single-subject randomized } \\
\text { controlled trial with } \\
\text { I2-week follow-up using } \\
\text { graduated measuring cups }\end{array}$ & $\begin{array}{l}\text { Bedside-thickened } \\
\text { fluids vs pre-thickened } \\
\text { fluids }\end{array}$ & $\begin{array}{l}\text { Total daily fluid intake: } \\
785 \text { vs } 795 \text { mL (NS) }\end{array}$ \\
\hline Robbins et $\mathrm{al}^{13}$ & $\begin{array}{l}\text { Hospital inpatients } \\
\text { and residential } \\
\text { care (USA) }\end{array}$ & $515(36 I)$ & $\begin{array}{l}\text { Non-blinded parallel } \\
\text { randomized controlled trial } \\
\text { with 3-month follow-up }\end{array}$ & $\begin{array}{l}\text { Thin fluids with } \\
\text { chin down posture } \\
\text { vs mildly thick or } \\
\text { extremely thick fluids }\end{array}$ & $\begin{array}{l}\text { Dehydration: } \\
2.3 \% \text { vs } 5.9 \% \text { (no } \\
\text { statistical analysis) }\end{array}$ \\
\hline Vivanti et $\mathrm{al}^{30}$ & $\begin{array}{l}\text { Hospital inpatients } \\
\text { (Australia) }\end{array}$ & 25 (unreported) & $\begin{array}{l}\text { Cross-sectional } \\
\text { observational study of single } \\
\text { group using CMS method }\end{array}$ & Thickened fluids only & $\begin{array}{l}\text { Total daily fluid intake: } \\
\mathrm{I}, 37 \mathrm{I} \mathrm{mL}\end{array}$ \\
\hline
\end{tabular}

Note: CMS (consumption monitoring system) method records the percentage (none, $25 \%, 50 \%, 75 \%$, all) of each menu item consumed. Abbreviations: TMF, texture-modified food and fluids; NS, nonsignificant. 
with variation in level of function and proportion of people with dementia.

The studies identified by this review suggest that in people with dementia, TMF will reduce the risk of aspiration as seen on VFSS but that more than half will aspirate regardless of intervention. On the contrary, TMF was not clearly demonstrated to reduce clinically significant episodes of aspiration and related pneumonia. The only randomized controlled trial that included a majority of subjects with dementia was unable to identify any beneficial clinical outcomes, with no difference in the incidence of pneumonia or death over 3 months. ${ }^{13}$ This is in keeping with a recent international expert meeting on oropharyngeal dysphagia in older people that was unable to recommend the use of TMF for the reduction of aspiration pneumonia risk. ${ }^{7}$ Another study found that non-adherence with TMF was associated with the increased incidence of hospital admissions and death, ${ }^{22}$ but non-adherent patients are likely to have a poorer prognosis anyway. There are no studies about the impact of TMF on the quality of life in people with dementia or residential care.

There are no studies that specifically investigate the nutritional outcomes in people living with dementia on TMF. A number of studies reported that people in residential care are unlikely to meet their recommended daily energy requirements regardless of the type of diet and those on TMF have a lower daily energy intake compared with patients on a normal diet. There are no studies that address malnutrition as a primary clinical outcome. The studies identified by this review suggest that patients in hospital and residential care on TMF do not maintain their daily fluid requirements, consistent with conclusions from the stroke literature. ${ }^{6}$ There were no studies that translate daily fluid intake to hydration status including using surrogate outcome measures such as thirst, biochemical markers, or the need for parenteral fluids.

Adherence to TMF is variable depending on the setting, but there is no clear correlation with the type of food or fluid modification, age, and severity of dysphagia. One study demonstrated that staff education and TMF availability may improve adherence in hospital inpatients, ${ }^{32}$ whereas another study attempted to improve the appearance of TMF in order to increase adherence. ${ }^{28}$

This review has several limitations including the small number of English-only studies identified, the heterogeneity of studies, and many with methodological bias and flawed design. Most studies had very small sample sizes and relatively short follow-up time periods. The populations studied were heterogeneous, with no studies consisting of subjects with dementia exclusively. Although five randomized controlled trials were included, some of these were weakened by the lack of an adequate control group with authors arguing that it would be unethical to include a no-treatment group. Further ethical considerations were raised by the most robust randomized controlled trial that introduced a selection bias. ${ }^{13}$ Their sample consisted of patients who aspirated or did not aspirate on VFSS no matter which intervention was used. All were single blinded as the nature of the intervention precluded the ability to blind the direct care providers.

There are multiple gaps in the literature as described above which should be considered for future research. The current evidence is not strong enough to preclude unmodified food and fluid as a control group on ethical grounds in future randomized clinical trials. These should explore further the relationship between TMF in people with dementia and clinically relevant outcomes of malnutrition, dehydration, and morbidity and mortality. Given the progressive and incurable nature of dysphagia secondary to dementia, incorporation of quality of life measures is essential. Other important research focuses are enhancing TMF as a nutritional alternative to normal diet through enrichment and examining alternative strategies for managing aspiration risk in people with dementia such as comfort feeding with better oral care or usage of free water protocols.

TMF is used regularly in patients with dysphagia secondary to dementia despite a lack of data and evidence for their beneficial effect on clinical outcomes including aspiration, pneumonia, hydration, nutrition, morbidity, and mortality. Further research is urgently needed to guide clinical practice on the management of aspiration and the use of TMF in people living with dementia who have aspiration and dysphagia.

\section{Acknowledgment}

We acknowledge the support of the Ageing and Alzheimer's Institute.

\section{Disclosure}

The authors report no conflicts of interest in this work.

\section{References}

1. Khan A, Carmona R, Traube M. Dysphagia in the elderly. Clin Geriatr Med. 2014;30(1):43-53.

2. Australian New Zealand Society for Geriatric Medicine. Australian and New Zealand Society for Geriatric Medicine. Position statement dysphagia and aspiration in older people*. Australas J Ageing. 2011; 30(2):98-103.

3. Leder SB, Judson BL, Sliwinski E, Madson L. Promoting safe swallowing when puree is swallowed without aspiration but thin liquid is aspirated: nectar is enough. Dysphagia. 2013;28(1):58-62.

4. Flynn E, Smith C, Walsh C, Walshe M. Modifying the consistency of foods and fluids for swallowing difficulties in dementia (Protocol) Cochrane Database Syst Rev. 2014;4:CD011077. 
5. Carrion S, Roca M, Costa A, et al. Nutritional status of older patients with oropharyngeal dysphagia in a chronic versus an acute clinical situation. Clin Nutr. 2016;36(4):1110-1116.

6. Foley N, Teasell R, Salter K, Kruger E, Martino R. Dysphagia treatment post stroke: a systematic review of randomised controlled trials. Age Ageing. 2008;37(3):258-264.

7. Wirth R, Dziewas R, Beck AM, et al. Oropharyngeal dysphagia in older persons - from pathophysiology to adequate intervention: a review and summary of an international expert meeting. Clin Interv Aging. 2016;11: 189-208.

8. Andersen UT, Beck AM, Kjaersgaard A, Hansen T, Poulsen I. Systematic review and evidence based recommendations on texture modified foods and thickened fluids for adults ( $\geq 18$ years) with oropharyngeal dysphagia. e-SPEN J. 2013;8(4):e127-e134.

9. Alagiakrishnan K, Bhanji RA, Kurian M. Evaluation and management of oropharyngeal dysphagia in different types of dementia: a systematic review. Arch Gerontol Geriatr. 2013;56(1):1-9.

10. Affoo RH, Foley N, Rosenbek J, Shoemaker JK, Martin RE. Swallowing dysfunction and autonomic nervous system dysfunction in Alzheimer's disease: a scoping review of the evidence. J Am Geriatr Soc. 2013;61(12): 2203-2213.

11. Hanson LC, Ersek M, Gilliam R, Carey TS. Oral feeding options for people with dementia: a systematic review. J Am Geriatr Soc. 2011; 59(3):463-472.

12. Logemann JA, Gensler G, Robbins J, et al. A randomized study of three interventions for aspiration of thin liquids in patients with dementia or Parkinson's disease. J Speech Lang Hear Res. 2008;51(1): 173-183.

13. Robbins J, Gensler G, Hind J, et al. Comparison of 2 interventions for liquid aspiration on pneumonia incidence: a randomized trial. Ann Intern Med. 2008;148(7):509-518.

14. Hines S, McCrow J, Abbey J, Gledhill S. Thickened fluids for people with dementia in residential aged care facilities. Int $J$ Evid Based Healthc. 2010;8(4):252-255.

15. Cormier D, Harper DW, O'Hara PA, et al. Pureed diet: prevalence and reported reasons for use in a long-term care hospital. J Can Diet Assoc. 1994;55(3):121-124.

16. Groher ME, McKaig TN. Dysphagia and dietary levels in skilled nursing facilities. J Am Geriatr Soc. 1995;43(5):528-532.

17. Keller HH, Chambers LW, Fergusson DA, et al. A mix of bulk and ready-to-use modified-texture food: impact on older adults requiring dysphagic food. Can J Aging. 2012;31(3):335-348.

18. Nowson CA, Sherwin AJ, McPhee JG, Wark JD, Flicker L. Energy, protein, calcium, vitamin $\mathrm{D}$ and fibre intakes from meals in residential care establishments in Australia. Asia Pac J Clin Nutr. 2003;12(2): $172-177$.
19. Castellanos VH, Butler E, Gluch L, Burke B. Use of thickened liquids in skilled nursing facilities. J Am Diet Assoc. 2004;104(8):1222-1226.

20. Rosler A, Pfeil S, Lessmann H, Hoder J, Befahr A, von Renteln-Kruse W. Dysphagia in dementia: influence of dementia severity and food texture on the prevalence of aspiration and latency to swallow in hospitalized geriatric patients. J Am Med Dir Assoc. 2015;16(8):697-701.

21. Taniguchi E, Asakura K, Murakami K, Masayasu S, Sasaki S. Relationship between diet texture and discharge due to deteriorating health condition in nursing home residents in Japan: a multicenter 1-year prospective study. Asia Pac J Public Health. 2014;26(5):507-516.

22. Low J, Wyles C, Wilkinson T, Sainsbury R. The effect of compliance on clinical outcomes for patients with dysphagia on videofluoroscopy. Dysphagia. 2001;16(2):123-127.

23. Wright L, Cotter D, Hickson M, Frost G. Comparison of energy and protein intakes of older people consuming a texture modified diet with a normal hospital diet. J Hum Nutr Diet. 2005;18(3):213-219.

24. McCormick SE, Stafford KM, Saqib G, Chroinin DN, Power D. The efficacy of pre-thickened fluids on total fluid and nutrient consumption among extended care residents requiring thickened fluids due to risk of aspiration. Age Ageing. 2008;37(6):714-715.

25. Bannerman E, McDermott K. Dietary and fluid intakes of older adults in care homes requiring a texture modified diet: the role of snacks. J Am Med Dir Assoc. 2011;12(3):234-239.

26. Johnson RM, Smiciklas-Wright H, Soucy IM, Rizzo JA. Nutrient intake of nursing-home residents receiving pureed foods or a regular diet. J Am Geriatr Soc. 1995;43(4):344-348.

27. Massoulard A, Bonnabau H, Gindre-Poulvelarie L, et al. Analysis of the food consumption of 87 elderly nursing home residents, depending on food texture. J Nutr Health Aging. 2011;15(3):192-195.

28. Germain I, Dufresne T, Gray-Donald K. A novel dysphagia diet improves the nutrient intake of institutionalized elders. J Am Diet Assoc. 2006;106(10):1614-1623.

29. Dahl WJ, Whiting SJ, Tyler RT. Protein content of pureed diets: implications for planning. Can J Diet Pract Res. 2007;68(2):99-102.

30. Vivanti AP, Campbell KL, Suter MS, Hannan-Jones MT, Hulcombe JA. Contribution of thickened drinks, food and enteral and parenteral fluids to fluid intake in hospitalised patients with dysphagia. J Hum Nutr Diet. 2009;22(2):148-155.

31. Shim JS, Oh BM, Han TR. Factors associated with compliance with viscosity-modified diet among dysphagic patients. Ann Rehabil Med. 2013;37(5):628-632.

32. Rosenvinge SK, Starke ID. Improving care for patients with dysphagia. Age Ageing. 2005;34(6):587-593

33. Colodny N. Dysphagic independent feeders' justifications for noncompliance with recommendations by a speech-language pathologist. Am J Speech Lang Pathol. 2005;14(1):61-70. 


\section{Supplementary materials}

Table SI Comparison between the Australian clinical food and fluid texture scale, the National Dysphagia Diet (US) and the UK (adult) texture classification systems for individuals with dysphagia

\begin{tabular}{|c|c|c|}
\hline \multicolumn{3}{|l|}{ Food texture } \\
\hline Australia & USA & UK \\
\hline Regular & Regular & Normal \\
\hline Texture $\mathrm{A}$ - soft $(1.5 \mathrm{~cm})$ & Dysphagia advanced $(2.5 \mathrm{~cm})$ & Texture $\mathrm{E}(\mathrm{I} .5 \mathrm{~cm})$ \\
\hline Texture $B-$ minced and moist $(0.5 \mathrm{~cm})$ & Dysphagia mechanically altered $(0.6 \mathrm{~cm})$ & Texture D \\
\hline \multirow[t]{3}{*}{ Texture C - smooth pureed } & Dysphagia puree & Texture $\mathrm{C}$ \\
\hline & & Texture B \\
\hline & & Texture A \\
\hline \multicolumn{3}{|l|}{ Fluid viscosity } \\
\hline Australia & USA & UK \\
\hline \multirow[t]{2}{*}{ Regular } & Thin $\mathrm{I}-50 \mathrm{cP}$ & Thin fluid \\
\hline & & Naturally thick fluid \\
\hline Level I50 - mildly thick & Nectar $5 \mathrm{I}-350 \mathrm{cP}$ & Thickened fluid - stage I \\
\hline Level 400 - moderately thick & Honey $35 \mathrm{I}-\mathrm{I}, 750 \mathrm{cP}$ & Thickened fluid - stage 2 \\
\hline Level 900 - extremely thick & Spoon or pudding $>1,750 \mathrm{cP}$ & Thickened fluid - stage 3 \\
\hline
\end{tabular}

Note: Reproduced with permission from Dietitians Association of Australia, Speech Pathology Association of Australia Limited. Texture-modified foods and thickened fluids as used for individuals with dysphagia: Australian standardised labels and definitions. Nutr Diet. 2007;64(S2):S53-S76.'

Table S2 Search terms used in Medline

I. dysphagia.mp. or Deglutition Disorders/

2. oropharyngeal dysphagia.mp.

3. Deglutition/ or deglutition.mp.

4. deglutition disorders.mp. not I [ $\mathrm{mp}=$ title, abstract, original title, name of substance word, subject heading word, keyword heading word, protocol supplementary concept word, rare disease supplementary concept word, unique identifier]

5. aspiration.mp.

6. swallowing.mp.

7. I or 2 or 3 or 4 or 5 or 6

8. aged.mp. or "Aged, 80 and over"/ or Aged/ or Health Services for the Aged/

9. elderly.mp.

10. geriatrics.mp. or Geriatrics/

II. gerontology.mp.

12. Geriatric Assessment/

13. 8 or 9 or 10 or 11 or 12

14. Inpatients/ or inpatient*.mp. or Hospitalization/

15. acute care.mp.

16. hospitalisation.mp.

17. hospital care.mp.

18. Patient Admission/ or admission*.mp.

19. 14 or 15 or 16 or 17 or 18

20. dementia.mp. [ $\mathrm{mp}=$ title, abstract, original title, name of substance word, subject heading word, keyword heading word, protocol supplementary concept word, rare disease supplementary concept word, unique identifier]

\section{Table S2 (Continued)}

2I. Dementia/ or Delirium, Dementia, Amnestic, Cognitive Disorders/ or Frontotemporal Dementia/ or Dementia, Vascular/

22. Alzheimer Disease/ or alzheimer.mp.

23. 20 or 21 or 22

24. thick* liquid*.mp.

25. modified diet*.mp.

26. diet* modification*.mp.

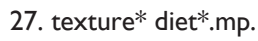

28. texture* modification*.mp.

29. modified texture*.mp.

30. thick* fluid*.mp.

31. modified liquid*.mp.

32. modified fluid*.mp.

33. modified food*.mp.

34. food modification*.mp.

35. modified solid*.mp.

36. 24 or 25 or 26 or 27 or 28 or 29 or 30 or 31 or 32 or 33 or 34 or 35

37. 7 and 23

38. 7 and 13 and 19

39. 36 and 23

40. 36 and 13

4 I. 37 or 38 or 39 or 40

(Continued) 
Table S3 Results of studies that describe the prevalence of use of TMF in dementia and residential care facilities

\begin{tabular}{|c|c|c|c|}
\hline Study & Setting & $\begin{array}{l}\text { Number of subjects } \\
\text { (subjects with dementia) }\end{array}$ & Prevalence of use of TMF \\
\hline Castellanos et $\mathrm{al}^{2}$ & 252 nursing homes (USA) & 25,470 (not reported) & $\begin{array}{l}8.3 \% \text { thickened fluids } \\
(60.1 \% \text { mildly, } 33.1 \% \text { moderately, } \\
6.3 \% \text { extremely thick })\end{array}$ \\
\hline Cormier et al ${ }^{3}$ & $\begin{array}{l}\text { I long-term care and rehabilitation } \\
\text { facility (Canada) }\end{array}$ & $424(143)$ & $25.9 \%$ pureed diet \\
\hline Groher and McKaig ${ }^{4}$ & 2 nursing homes (USA) & 658 (1 I2 in modified diet group) & $31 \%$ modified diet \\
\hline \multirow[t]{2}{*}{ Keller et a ${ }^{5}$} & I continuing care facility (Canada) & $36 \mathrm{I}$ (not reported) & $13 \%$ modified diet \\
\hline & I nursing home (Canada) & 73 (not reported) & $29 \%$ modified diet \\
\hline \multirow[t]{2}{*}{ Nowson et al ${ }^{6}$} & I nursing home (Australia) & $139(60)$ & $29 \%$ soft diet, $38 \%$ pureed diet \\
\hline & I hostel (Australia) & 76 (not reported) & $10 \%$ soft diet, $0 \%$ pureed diet \\
\hline
\end{tabular}

Abbreviation: TMF, texture-modified food and fluids.

Table S4 Results of studies examining adherence as an outcome in subjects on TMF

\begin{tabular}{|c|c|c|c|c|}
\hline Study & Setting & $\begin{array}{l}\text { Number of subjects } \\
\text { (subjects with dementia) }\end{array}$ & Methods & Outcomes \\
\hline Colodny ${ }^{7}$ & $\begin{array}{l}\text { Residential care patients } \\
\text { who are independent with } \\
\text { feeding (USA) }\end{array}$ & 63 (unreported) & Qualitative interview & $\begin{array}{l}\text { Reasons for non-adherence: } \\
\text { - Denial of dysphagia and minimizing } \\
\text { condition }(50 \%) \\
\text { - Dissatisfaction with texture and } \\
\text { taste }(39.7 \%) \\
\text { - Informed decision and calculated } \\
\text { risk }(22.2 \%) \\
\text { - Rationalizing non-adherence }(21.4 \%)\end{array}$ \\
\hline Low et $\mathrm{al}^{8}$ & $\begin{array}{l}\text { Residential care patients } \\
\text { and people at home who } \\
\text { were recommended for } \\
\text { modified food (59\%) or } \\
\text { fluids ( } 93 \% \text { ) after VFSS } \\
\text { (New Zealand) }\end{array}$ & $140(11)$ & $\begin{array}{l}\text { Retrospective cohort } \\
\text { study with I8-month } \\
\text { follow-up }\end{array}$ & Non-adherence: $21 \%$ \\
\hline Robbins et al ${ }^{9}$ & $\begin{array}{l}\text { Hospital inpatients and } \\
\text { residential care patients } \\
\text { who aspirate on thin fluids } \\
\text { and perform equally on } \\
\text { all three interventions on } \\
\text { VFSS (USA) }\end{array}$ & $104(104)$ & $\begin{array}{l}\text { Non-blinded parallel } \\
\text { randomized controlled } \\
\text { trial with weekly } \\
\text { measures of adherence } \\
\text { over } 3 \text { months }\end{array}$ & $\begin{array}{l}\text { Non-adherence: } 43 \% \text { for thin fluids } \\
\text { with chin down posture vs } 27 \% \\
\text { for mildly thick fluids vs } 19 \% \text { for } \\
\text { extremely thick fluids }\end{array}$ \\
\hline $\begin{array}{l}\text { Rosenvinge } \\
\text { and Starke }\end{array}$ & Hospital inpatients (UK) & $\begin{array}{l}31 \text { before, } 54 \text { after } \\
\text { (unreported) }\end{array}$ & $\begin{array}{l}\text { Sequential observational } \\
\text { study before and after } \\
\text { 2-month targeted } \\
\text { intervention }\end{array}$ & $\begin{array}{l}\text { Non-adherence for thickened fluids: } \\
52 \% \text { before, } 36 \% \text { after }(P<0.05) \\
\text { Non-adherence for modified diet: } \\
18 \% \text { before, } 21 \% \text { after (NS) }\end{array}$ \\
\hline Shim et al" & $\begin{array}{l}\text { Hospital inpatients who } \\
\text { were recommended for } \\
\text { modified food or fluids } \\
\text { after VFSS (South Korea) }\end{array}$ & $62(5)$ & $\begin{array}{l}\text { Retrospective cohort } \\
\text { study with outpatient } \\
\text { follow-up and } \\
\text { qualitative interview }\end{array}$ & $\begin{array}{l}\text { Non-adherence: I0\% in hospital, } \\
43.5 \% \text { in outpatient }(P=0.00 \mathrm{I}) \\
\text { Reasons for non-adherence: } \\
\text { - Dissatisfaction with texture }(40 \%) \\
\text { - Dissatisfaction with taste }(40 \%) \\
\text { - Difficulty in preparation }(20 \%) \\
\text { - Difficulty in swallowing }(20 \%)\end{array}$ \\
\hline
\end{tabular}

Abbreviations: NS, non significant; TMF, texture-modified food and fluids; VFSS, videofluoroscopic swallowing studies. 


\section{References}

1. Dietitians Association of Australia, Speech Pathology Association of Australia Limited. Texture-modified foods and thickened fluids as used for individuals with dysphagia: Australian standardised labels and definitions. Nutr Diet. 2007;64(S2):S53-S76.

2. Castellanos VH, Butler E, Gluch L, Burke B. Use of thickened liquids in skilled nursing facilities. J Am Diet Assoc. 2004;104(8): 1222-1226.

3. Cormier D, Harper DW, O'Hara PA, et al. Pureed diet: prevalence and reported reasons for use in a long-term care hospital. J Can Diet Assoc. 1994;55(3):121-124.

4. Groher ME, McKaig TN. Dysphagia and dietary levels in skilled nursing facilities. J Am Geriatr Soc. 1995;43(5):528-532.

5. Keller HH, Chambers LW, Fergusson DA, et al. A mix of bulk and ready-to-use modified-texture food: impact on older adults requiring dysphagic food. Can J Aging. 2012;31(3):335-348.
6. Nowson CA, Sherwin AJ, McPhee JG, Wark JD, Flicker L. Energy, protein, calcium, vitamin $\mathrm{D}$ and fibre intakes from meals in residential care establishments in Australia. Asia Pac J Clin Nutr. 2003;12(2):172-177.

7. Colodny N. Dysphagic independent feeders' justifications for noncompliance with recommendations by a speech-language pathologist. Am J Speech Lang Pathol. 2005;14(1):61-70.

8. Low J, Wyles C, Wilkinson T, Sainsbury R. The effect of compliance on clinical outcomes for patients with dysphagia on videofluoroscopy. Dysphagia. 2001;16(2):123-127.

9. Robbins J, Gensler G, Hind J, et al. Comparison of 2 interventions for liquid aspiration on pneumonia incidence: a randomized trial. Ann Intern Med. 2008;148(7):509-518.

10. Rosenvinge SK, Starke ID. Improving care for patients with dysphagia. Age Ageing. 2005;34(6):587-593

11. Shim JS, Oh BM, Han TR. Factors associated with compliance with viscosity-modified diet among dysphagic patients. Ann Rehabil Med 2013;37(5):628-632.
Clinical Interventions in Aging

\section{Publish your work in this journal}

Clinical Interventions in Aging is an international, peer-reviewed journal focusing on evidence-based reports on the value or lack thereof of treatments intended to prevent or delay the onset of maladaptive correlates of aging in human beings. This journal is indexed on PubMed Central, MedLine,

\section{Dovepress}

CAS, Scopus and the Elsevier Bibliographic databases. The manuscript management system is completely online and includes a very quick and fair peer-review system, which is all easy to use. Visit http://www.dovepress. com/testimonials.php to read real quotes from published authors. 